\begin{tabular}{|l|l|}
\hline \multirow{2}{*}{$\begin{array}{c}\text { TOURISM } \\
\text { AND }\end{array}$} & Journal of Tourism\&Management Research \\
MANAGEMENT & ISSN: 2149-6528 \\
ANNTIERNATONALJOURNAL & 2021 Vol. 6, Issue.1 \\
& http://ottomanjournal.com/index.html \\
\hline
\end{tabular}

\title{
Understanding the Impacts of the Covid-19 on Travel Behaviour
}

\begin{abstract}
COVID-19 is causing serious economic effects on the global economy as well as direct health effects. The virus has negative effects in almost all sectors but the travel and tourism industry has been the worst affected of all economic sectors. This paper aimed to explore how coronavirus could change traveler preferences in the post-pandemic period. For this purpose 284 data were collected from the participants by an online survey. Descriptive statistics was applied for data analysis. The findings show that most of the participants have the uncertainty-driven feeling in their travels. There will be a tendency towards keeping a safe social distance, paying attention to health and safety precautions. At the same time transportation vehicles, accommodations and types of tourism, where the safe social distance is maintained, will be preferred. The research findings contribute to the existing literature and are intended to help the industry build new approaches.
\end{abstract}

Keywords: Travel behavior, Tourist behavior, Covid-19, Post-pandemic

JEL Classification: Z32, L83, M10

Submitted: 17.12.2020; Accepted: 15.04 .2021

Serap Ozdemir Guzel, PhD. Department of Hotel, Restaurant and Catering Services, Istanbul University-Cerrahpasa, Istanbul-Turkey. Tel: +90 021259490 83,

E-mail: serap.guzel@istanbul.edu.tr

Leyla Sisik, Independent Researcher. Department of Tourism Management, Instanbul University

E-mail: leylasisik@gmail.com

\section{Introduction}

The travel and tourism industry is very dynamic and there are so many significant threats to tourism such as health concerns, terrorism, wars and politics (Chebli and Said, 2020). Those threats have a great influence on tourists' behavior in consumption. So, their consuming behaviour changes due to fear and confusion. (Bodosca, Gheorghe and Nistroreonu, 2014). In addition to this, tourists want to stay safe while travelling and prefer safe and secure destinations (Yousaf, Amin and Santas, 2018). 
The tourism industry is faced with many regional and international crises. Covid-19 pandemic period is one of those. Coronavirus disease ,also called COVID-19, declared by the World Health Organisation (WHO) in March, 2020, is a global pandemic. Covid-19 pandemic has impacted all the sectors since it started to spread to many other countries. It is dramatically affecting people's lives in many ways while changing daily routine and habits of people all over the world. Global lockdowns, travel restrictions, border shutdowns and quarantines brought life to a standstill. Governments recently started to ease restrictions. All countries are trying to return to normal social and economic activities but the virus is not yet under control.

The pandemic has devastated tourism movements worldwide. Tourism has been the most affected sector. Most of the tourism enterprises couldn't operate their facilities and services and some are still not working at full capacity due to travel restrictions. Restrictions on travel which are introduced in response to the COVID-19 pandemic, continue to hit global tourism hard, with the latest report on October, 2020 from the World Tourism Organization (UNWTO) showing a 70\% fall in international arrivals during the first eight months of 2020 (UNWTO, 2020). Ali and Cobanoglu (2020) reported that compared to last year, the travel industry, which includes businesses such as airlines, hotels and restaurants, will shrink by $50 \%$ in 2020, which would mean a significant loss of jobs and revenue. The number of international travelers could shrink from 1.4 billion to fewer than 1 billion people. That would be the first time the international traveler number has fallen that low since 2015 .

According to UNWTO, it is too early to estimate the full impact of COVID-19 on international tourism. But it is very realistic to say COVID-19 will keep changing traveller's preferences as tourism will be the worst affected sector due to pandemic. So the tourism industry is starting to function again but they have to develop new strategies to minimize the negative effects of this crisis as the pandemic is still going on. Social distancing is very important to slow the spread of the virus. Sanitation and hygiene practices are important for all to fight against coronavirus. Tourism industry makes an effort to adapt to the "new normal" and to understand tourist travel behavior and meet the expectations which includes some considerations, new health protocols, ensuring sufficient social distancing, safety and hygiene measures by cooperating closely with the World Health Organization (WHO).

When the studies on tourist behavior are examined (Chebli and Said, 2020; Enger, Saxon, Suo and Yu, 2020; Ivanova, Ivanov and Ivanov, 2020; Turnsek, Brumen, Rangus, Gorenak, Mekinc and Stuhec, 2020), generally, it is seen that (1) during individual travels and family travels in particular, social distance come to the fore; (2) special vehicles are and will be preferred; (3) Tourism businesses that comply with social distance, hygiene and sanitation rules, will be preferred; (4) there will be mobility within the scope of close distance travels and domestic tourism; (5) alternative tourism types will be preferred; and (6) travel insurance will not be skipped in these studies.

In the context of the above, what about the changes in tourist behaviours? How will it shape during and after Covid-19? The study adopts a demand-side perspective and focuses on how coronavirus could affect the tourist behaviours, what will be the priorities they need to acquire during the travels. Besides, research findings contribute to the existing literature and it is important to study how the tourism and travel industry will begin to take shape, and are also important for the sector to understand travelers' behaviours for recovery plans and actions.

\section{Literature Review}

\subsection{Tourist Behaviours}

The topic of tourist behaviour depends upon, interacts with, and occasionally determines other components of tourism. Tourist behaviour is powerfully connected to and often contingent upon marketing activities: it strongly shapes the wellbeing of many small businesses, and it can generate considerable socio-cultural and environmental impacts. All sorts of people who 
are making decisions about tourists are concerned with tourist behaviour because their job involves making an enabling decision or policy choice about tourist activities (Pearce, 2005: 9-11). Tourism organizations require a wide variety of data on tourist behaviour, including; the statistical profiles of tourists, statistical records of tourist behaviour, how tourists make purchasing decisions, who makes the purchase decision, when the purchase decision is made, consumer perceptions, tourist satisfaction, the identification of trends in tourist behaviour, product positioning in relation to competitors, cultural and national differences in tourist behaviour. The industry must understand what determines whether or not customers will be satisfied with the products it offers and it is important to recognize the trends in tourist demands so that tourism organizations can anticipate them and develop new products accordingly (Swarbrooke and Horner, 2007: 154-155).

Tourist behaviour is affected by many internal and external factors (Andrades, Dimanche and Ilkevich, 2015). These factors may arouse fear and anxiety in tourists. As a respond, this causes tourists be extra cautious in their travel decision-making. The trust factor and perceived risk factors are known to be at the forefront of tourists' consumption processes. (Chebli and Said, 2020). The Covid-19 epidemic also affects the tourist behavior as an external factor. The main rule of Covid-19 is to follow the social distance and hygiene precautions. At this point, social distance affects people's travel decisions. (De Vos, 2020). Tourists take the risk factor of their travels into consideration. While the number of people that they come into contact lessens, the risk also lessens. For this reason, in crowded spaces, transportation vehicles, accommodation businesses, food and beverage businesses, events and other places, the social distance and hygiene rule should be preferred. Tourists tend to avoid social contact during their travels (De Vos, 2020).

\subsection{Past Research on Covid 19}

It is seen that the studies discussed in the literature are made in two ways. Main emphasis is on the economic aspect. It is seen that studies on consumer behavior are limited (Ivanova et al., 2020). However, there are studies to understand Covid-19 and evaluate its effects during and after the Covid-19 process. Some of the topics covered in these studies are as follows:

- Tourist pysche (Kock, Norfelt, Josiassen, Assaf and Tsionas, 2020); Guest-host relationship (Kour, Jasrotia and Gupta, 2020); indigenous people (Carr, 2020).

- Impacts and implications for industry and research (Sigala, 2020); visions of travel and tourism (Lew, Cheers, Haywood, Brouder and Salazar, 2020).

- Impact on cultural tourism (Flew and Kirkwood, 2020); medical tourism (Tatum, 2020); city tourism (Jiricka, Brandenburg and Pröbstl-Haider, 2020); e-tourism (Gretzel, Fuhs, Baggio, Hoepken, Law, Neidhardt, Pesonen, Zanker and Xiang, 2020); distancing mass cruise tourism (Renaud, 2020); mountain tourism and second home tourism (Seraphin, 2020).

- Effects on expected revenues (Diaz-Sanchez and Obaco, 2020); social costs of tourism (Qui, Park, Song and Li, 2020); open market valuation (Sharma and Nicolau, 2020); effects of tourism economy (Mariolis, Rodousakis and Saklis, 2020).

- Impacts on the African tourism (Rogerson and Rogerson, 2020); on the Spanish tourism sector (Gil-Alana and Poza, 2020); on the Malaysian tourism sector (Foo, Chin, Tan and Phuah, 2020).

In the literature, there are limited studies dealing with tourist behaviour (Chebli and Said, 2020; Enger, Saxon, Suo and Yu, 2020; Ivanova et al, 2020; Turnsek, Brumen, Rangus, Gorenak, Mekinc and Stuhec, 2020). Chebli and Said (2020) found that Covid-19 will influence travel habits, and people will avoid traveling in groups, and being surrounded by a group of people. It was also seen that they would not travel without travel insurance. Hygiene and health conditions in the host destination will become important factors in travel decisions. The results of the study on Slovenian tourists conducted by Turnsek et al. (2020) show that it 
cannot be easily predicted how the general population will behave regarding their future travel avoidance since the opinions are not polarised in the extremes. Tourists will be susceptible to the context-specific factors of future travel decisions, such as assurances of health safety provided by the tourism industry.

The findings obtained by Ivanova et al. (2020) in their study in Bulgaria show that most of the respondents are ready to travel within two months after travel is allowed in the country. For their first trip, respondents will travel domestic, by their car and with their family. Hygiene, disinfection and reliable health system in a destination will be the leading factors in travellers' decisions. Women and older respondents have higher health and safety preferences than men and younger respondents do. According to Enger et al. (2020), participation in short-distance and domestic tourism activities is expected. Additionally, self-guided and selfdriven trips will dominate.

\section{Methodology}

\subsection{Sampling and Data Collection}

The data were collected via an online survey through professional and academic networks specialized in tourism. In the study, purposive and snowball sampling were used. In purposive sampling, a sample is selected from a small group that is part of the main population and has similarities with the main population (Bernard 2000; Robson 2002). It is particularly suitable for selecting informative and unique case studies (Neuman 2007: 323). In addition, judgmental sampling gives strength to the study on access to rich information in terms of method (Patton 2002: 231). For this purpose, the survey was applied to tourism professionals (private and academic staff). At the same time, it was tried to select people from different demographic and socio-cultural groups and to gather as many different opinions as possible. A total of 284 surveys were reached with the snowball sampling, which enables surveys to be conducted with the people they recommend. A total of 284 questionnaires were collected online among 25 April-02 May 2020. After deleting faulty responses, 280 questionnaires were used for the data analysis.

\subsection{Measures and Data Analysis}

In this study, it is aimed to examine the travel behavior of the tourists after Covid-19. For this purpose, a quantitative research method was used. Questionnaire was used as data collection technique. The questionnaire used in the research contains 17 items and demographic questions. The first three of the statements in the questionnaire are adapted from Thomas (2020) and other statements were developed by the authors. Items were measured using the 5point Likert scale ( $1=$ Strongly Disagree, 5=Strongly Agree) in the structured questionnaire. In the calculation of the appropriate sample size, the rule "the sample size should be 10 times greater than the number of items", which is widely accepted in the literature, has been taken into account (Roscoe, 1975; Sultana, 2020).

In the current study, the collected data was analyzed using descriptive statistics, crosstabulations, through IBM SPSS Statistics 21.

\section{Findings}

\subsection{Descriptive Statistics}

Demographic profiles of the respondents are given in the Table 1 below. $52.5 \%$ of respondents are female, and $46.1 \%$ are male. When examining the nationality of the respondents, $31.4 \%$ is Turkish and $11 \%$ is British. And the country of residence of respondents, $23.2 \%$ is Turkey, $15 \%$ is the United Kingdom and $11.1 \%$ is Germany. The respondents between 25-34 years of age constitute $43.2 \%$. Majority of the respondents have received undergraduate and postgraduate education. $60 \%$ of the participants are undergraduate graduates. 
Table 1. Sample profile $(n=280)$.

Demographic variable

\section{Gender}

Male

Female

46.1

52.5

Age

12-24 years

25-34 years

$35-44$ years

45-54 years

55-65+

\section{Education}

High School
Bachelor's Degree
Master's Degree
PhD

20.0

60.0

10.0

10.0

Nationality

Turkish

British

31.4

German

French

11.8

Malaysian

Austrain

Indian

American

Iranian

Italian

Others

Turkey
United Kingdom
Germany
Spain
Malaysia
France
Qatar
United States
Austria
United Arab Emirates
Others

23.2

15.0

11.1

6.4

5.7

5.0

5.0

4.6

2.5

2.1

19.4 
First the Cronbach's alpha value was checked and found as 0.708 and this represents an acceptable reliability level. Then the mean scores were checked. The responses given by the participants to the statements about travel behaviors after Covid-19 are given in Table 2 . When the frequency values for the statements are examined; more than half of the participants stated that they did not agree with the statement-1 "There will be no change in my travel behavior". The number of undecided is $23.6 \%$. Another indecisive statement, statement-2, is to continue their travels as before after Covid. Those who remain undecided in this statement are $25.7 \%$.

It is seen that $27.1 \%$ of the participants gave an indecisive response to statement-3 as to whether they will postpone their travels due to financial adversities. 39.6\% of the participants do not agree with the idea that they cannot travel for a while. While $45 \%$ definitely agreed with the idea that social distance rule would have priority in their travels (S-4), 23.6\% agreed.

Considering the social distance rule can also change the travel criteria, with the abolition of travel restrictions, the epidemic may change direction. In this context, when the participants are asked whether they plan to travel within a year, 23.6\% of the participants stated that they were indecisive, $40.8 \%$ of them stated that they would not postpone their travels and $35.7 \%$ of them stated that they would postpone their travels. The number of those who stated that they would not participate in outbound tourism movements for a while (S-6) is $43.6 \%$. The number of those who stated that they would participate in domestic tourism activities (S-9) is $47.1 \%$. Those who will not travel to destinations that are prominent in terms of mass tourism (S-7) are 59.2\%. In this context, will there be a trend towards rural tourism? (S-8). Based on this question, $36.1 \%$ of the participants were undecided and $42.8 \%$ stated that they would prefer rural tourism. The number of participants who would not prefer cruise travel (S-17) is $77.9 \%$.

Considering the social distance rule in travels, the question of how to choose transportation vehicles comes to the fore. In this sense, $54 \%$ of the participants agreed with statement-11 "I will travel with my car", while $24.6 \%$ of them were undecided, and $39.7 \%$ agree with statement-12 "I don't think of traveling by plane for a while", while the undecided constitute $23.9 \%$.

The responses given to the statements asking whether they will take into account the health and safety precautions criteria in the preferred country (S-13), accommodation (S-15) and transportation vehicles (S-14) in their travel preferences; $78.6 \%$ prefer countries where health and safety precautions are considered; $80.4 \%$ prefer to travel with airline companies in which health and safety precautions are considered, and $81.1 \%$ of them to stay in hotels where health and safety precautions are considered.

Table 2. Descriptive statistics of respondents on travel behavior after Covid-19.

\begin{tabular}{|l|l|l|l|l|l|l|l|l|l|l|l|l|l|}
\hline Statements & \multicolumn{2}{|l|}{$\begin{array}{l}\text { Strongly } \\
\text { Disagree }\end{array}$} & \multicolumn{2}{|l|}{ Disagree } & \multicolumn{2}{l|}{$\begin{array}{l}\text { Neither } \\
\text { Agree Nor } \\
\text { Disagree }\end{array}$} & \multicolumn{2}{l|}{ Agree } & \multicolumn{2}{l|}{$\begin{array}{l}\text { Strongly } \\
\text { Agree }\end{array}$} & Mean & $\begin{array}{l}\text { Standard } \\
\text { Dev. }\end{array}$ \\
\hline & $\mathrm{N}$ & $\%$ & $\mathrm{~N}$ & $\%$ & $\mathrm{~N}$ & $\%$ & $\mathrm{~N}$ & $\%$ & $\mathrm{~N}$ & $\%$ & & \\
\hline $\begin{array}{l}\text { S-1.There will be no } \\
\text { change in my travel } \\
\text { behavior. }\end{array}$ & 66 & 23.6 & 57 & 20.4 & 66 & 23.6 & 40 & 14.3 & 51 & 18.2 & 2.83 & 1.413 \\
\hline $\begin{array}{l}\text { S-2. I will continue to } \\
\text { travel as before. }\end{array}$ & 44 & 15.7 & 58 & 20.7 & 72 & 25.7 & 42 & 15 & 64 & 22.9 & 3.09 & 1.378 \\
\hline $\begin{array}{l}\text { S-3. Since I am } \\
\text { financially affected by } \\
\text { the epidemic, I will not } \\
\text { be able to travel for a } \\
\text { while. }\end{array}$ & 58 & 20.7 & 53 & 18.9 & 76 & 27.1 & 46 & 16.4 & 47 & 16.8 & 2.90 & 1.360 \\
\hline S-4. While travelling, & 7 & 2.5 & 26 & 9.3 & 55 & 19.6 & 66 & 23.6 & 126 & 45 & 3.99 & 1.117 \\
\hline
\end{tabular}




\begin{tabular}{|c|c|c|c|c|c|c|c|c|c|c|c|c|}
\hline $\begin{array}{l}\text { social distance will be } \\
\text { my priority. }\end{array}$ & & & & & & & & & & & & \\
\hline $\begin{array}{l}\text { S-5. I do not think of } \\
\text { traveling over a period } \\
\text { of one year. }\end{array}$ & 64 & 22.9 & 50 & 17.9 & 66 & 23.6 & 47 & 16.8 & 53 & 18.9 & 2.91 & 1.420 \\
\hline $\begin{array}{l}\text { S-6. I will not prefer } \\
\text { outbound tourism } \\
\text { movements for a while. }\end{array}$ & 42 & 15 & 31 & 11.1 & 71 & 25.4 & 66 & 23.6 & 70 & 25 & 3.33 & 1.359 \\
\hline $\begin{array}{l}\text { S-7. I will not prefer } \\
\text { destinations that stand } \\
\text { out in terms of mass } \\
\text { tourism. }\end{array}$ & 22 & 7.9 & 23 & 8.2 & 69 & 24.6 & 69 & 24.6 & 97 & 34.6 & 3.70 & 1.243 \\
\hline $\begin{array}{l}\text { S-8. I will plan to travel } \\
\text { for rural tourism. }\end{array}$ & 21 & 7.5 & 38 & 13.6 & 101 & 36.1 & 65 & 23.2 & 55 & 19.6 & 3.34 & 1.159 \\
\hline $\begin{array}{l}\text { S-9. I will tend to only } \\
\text { domestic tourism for } \\
\text { the time being. }\end{array}$ & 27 & 9.6 & 38 & 13.6 & 83 & 29.6 & 65 & 23.2 & 67 & 23.9 & 3.38 & 1.253 \\
\hline $\begin{array}{l}\text { S-10. I will prefer } \\
\text { boutique hotels instead } \\
\text { of large hotels. }\end{array}$ & 32 & 11.4 & 36 & 12.9 & 74 & 26.4 & 63 & 22.5 & 75 & 29.8 & 3.40 & 1.314 \\
\hline $\begin{array}{l}\text { S-11. I will travel with } \\
\text { my car. }\end{array}$ & 33 & 11.8 & 27 & 9.6 & 69 & 24.6 & 52 & 18.6 & 99 & 35.4 & 3.56 & 1.364 \\
\hline $\begin{array}{l}\text { S-12. I don't think of } \\
\text { travelling by plane for a } \\
\text { while. }\end{array}$ & 62 & 22.1 & 40 & 14.3 & 67 & 23.9 & 45 & 16.1 & 66 & 23.6 & 3.05 & 1.462 \\
\hline $\begin{array}{l}\text { S-13. I will prefer } \\
\text { countries where health } \\
\text { and safety precautions } \\
\text { are considered. }\end{array}$ & 11 & 3.9 & 12 & 4.3 & 37 & 13.2 & 70 & 25 & 150 & 53.6 & 4.20 & 1.076 \\
\hline $\begin{array}{l}\text { S-14. I will travel with } \\
\text { airline companies in } \\
\text { which health and safety } \\
\text { precautions are } \\
\text { considered. }\end{array}$ & 7 & 2.5 & 14 & 5 & 34 & 12.1 & 77 & 27.5 & 148 & 52.9 & 4.23 & 1.012 \\
\hline $\begin{array}{l}\text { S-15. I will stay in } \\
\text { hotels where health and } \\
\text { safety precautions are } \\
\text { considered. }\end{array}$ & 6 & 2.1 & 10 & 3.6 & 37 & 13.2 & 65 & 23.2 & 162 & 57.9 & 4.31 & .976 \\
\hline $\begin{array}{l}\text { S-16. I will not prefer } \\
\text { the most populated } \\
\text { cities for my upcoming } \\
\text { vacations. }\end{array}$ & 20 & 7.1 & 28 & 10 & 65 & 23.2 & 67 & 23.9 & 100 & 35.7 & 3.71 & 1.247 \\
\hline $\begin{array}{l}\text { S-17. I will prefer } \\
\text { cruise vacations. }\end{array}$ & 173 & 61.8 & 45 & 16.1 & 42 & 15 & 7 & 2.5 & 13 & 4.6 & 1.72 & 1.101 \\
\hline
\end{tabular}

When the statments were analyzed by Nationality, the British participants responded differently to the S-1 "There will be no change in my travel behavior" compared to other nations. The majority stated that there would be no change in their travel behavior. German, British and citizens of other countries have stated that they continue to travel as before.

The British, Austrian, American and Malaysian participants stated that their travels were not affected financially (S-3). The number of undecided is high amongst the Turks and citizens of other countries. British, Indian, Malaysian, Turkish and others have stated that social distance is among their priorities (S-4). The majority of German and French citizens remained undecided.

While Malaysian and British participants agreed to statement-5 "I do not think of traveling over a period of one year", others, Iranian, French, Austrian and American stated that they did not. Turkish and German were also undecided. Turkish, Others, Indian and Malaysian agreed 
to statement-6 "I will not participate in outbound tourism movements for a while", while the Americans disagreed, and German, French and Austrian remained undecided.

When the destination preferences after Covid-19 were checked, the question "Which of the following countries would you prefer to travel to after Covid-19? (you may tick more than one)" was asked to the participants. The top 10 countries were specified according to UNWTO 2019 data and the other option was provided. The responses are given in Figure 1.

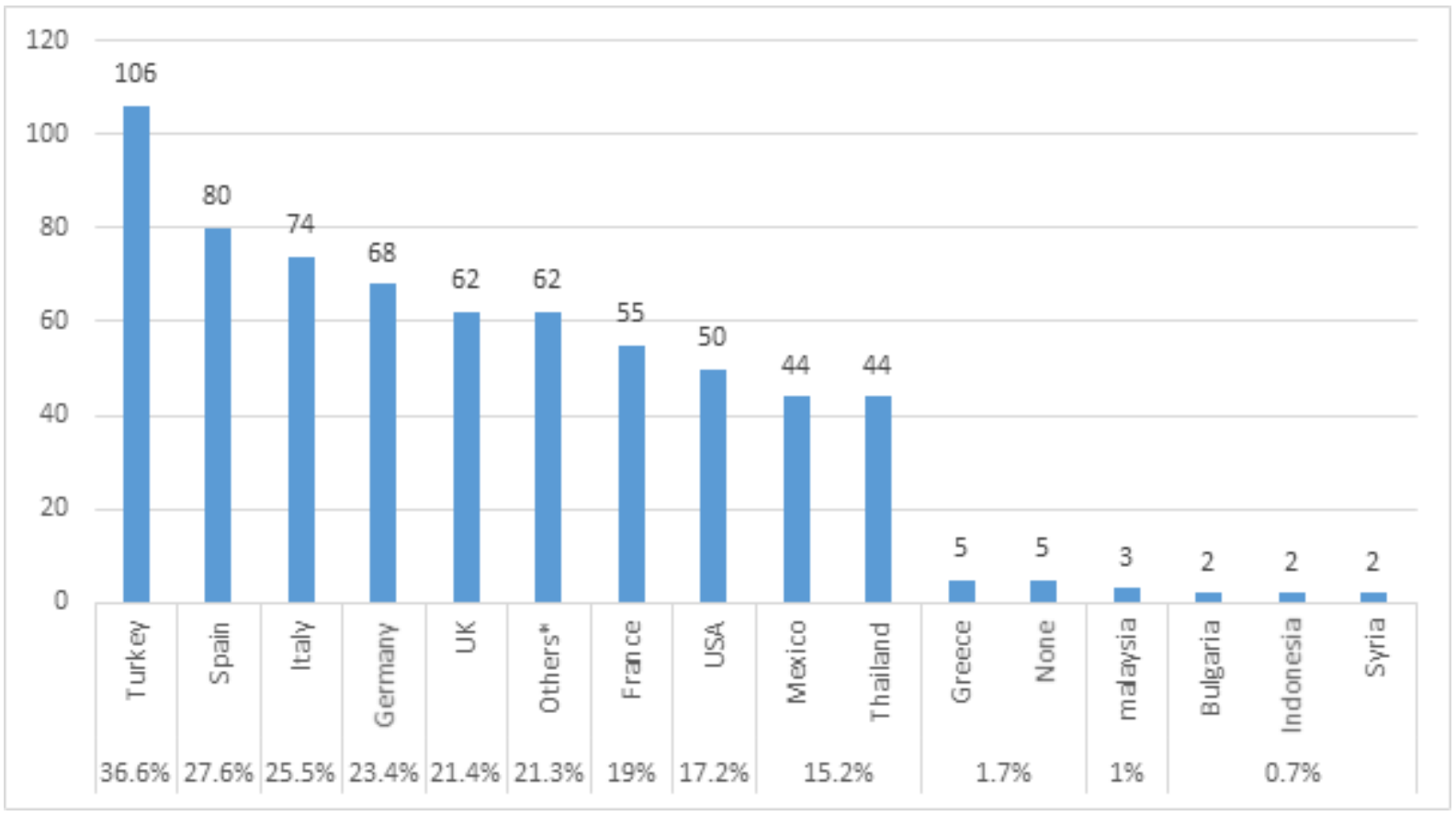

Figure 1. Preferring countries to travel after Covid-19.

Turkey, Spain, Italy, Germany, UK, which are among the top ten countries in terms of international tourists in UNWTO 2019, are among the top five choices of the participants. Preferred countries and the percentage of participants are as follows: Turkey $36.6 \%$, Spain $27.6 \%$, Italy $25.5 \%$, Germany $23.4 \%$, and the UK $21.4 \%$. While $1.7 \%$ of them say none, it is seen that they demand for countries other than the top ten countries. Once mentioned those countries have been evaluated under the other option. "Which of the following regions would you prefer for your trip after Covid-19? (you may tick more than one)" question was asked to the participants. Regional preferences of the participants are shown in Figure 2.

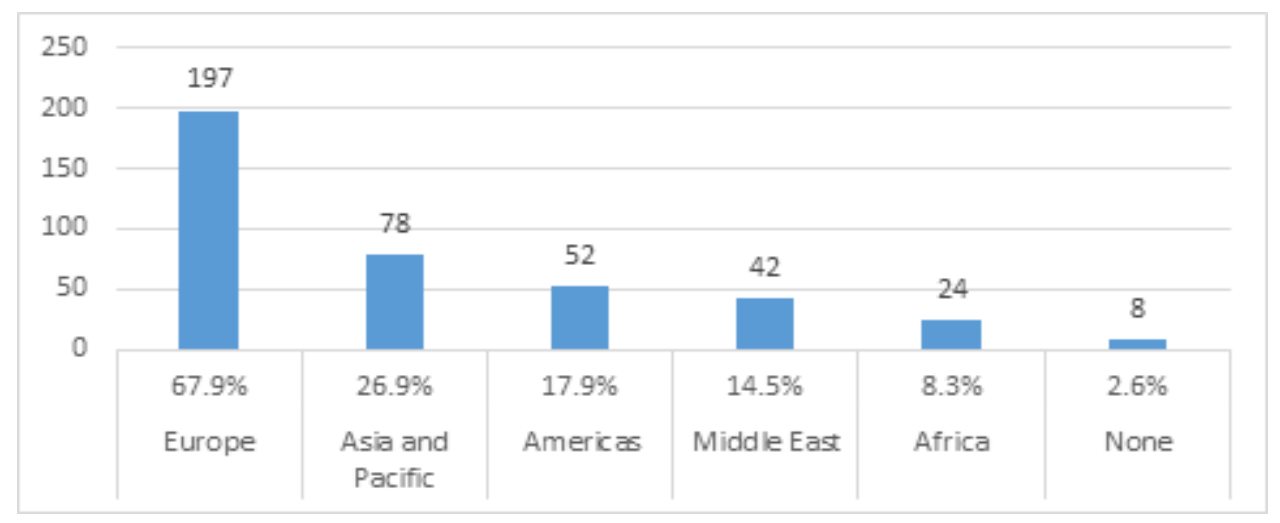

Figure 2. Preferring regions after Covid-19. 
According to Figure 2, it is seen that Europe is the most preferred. Europe has a share of $67.9 \%$. Europe is followed by Asia and the Pacific with $26.9 \%$. None option involved in $2.6 \%$ of the total.

\section{Conclusion, Implications and Limitations}

This study was conducted to determine tourist behavior and intentions after Covid-19. It makes the following theoritical and practical contribution to the literature. The data collected for this purpose have been analyzed and it is seen that the participants have the uncertaintydriven feelings about their travel trends. It is thought that the uncertainty of the process, the existence of the second wave expectation and the normalization process decisions that are to be taken by the countries are influential in experiencing this indecisiveness. After this postpandemic period, it is seen that the participants do not exactly have any plans to postpone their travels. This situation can be described as the unwillingness to lose an act that has already become a part of people's lives. In addition, they may not be able to receive a refund from businesses such as transportation, travel agency and accommodation for their previously planned and prepaid travels and they may have had to suspend their travels.

Another result obtained in the study is that social distance should be an important factor in travels. Moreover, the demand for mass tourism has changed. The majority of the participants stated that they would not travel to destinations that cater to mass tourism and big cities. In other words, it can be said that international travels will be affected by this process and sustainable tourism will be at the forefront instead of mass tourism. It has been determined that there will be a tendency towards rural and domestic tourism where safe social distance can be kept more easily. It is predicted that travelers will prefer relatively small hotels instead of large hotels in their accommodation preferences. Participants also state that they will pay attention to taking health and safety precautions in transportation, accommodation, food and beverage and other services in their touristic activities. Social distance will also be an important criterion in the post-covid period and there will be a group that will pay attention to this criterion. It is seen that this group is not in favor of choosing the means of transportation where the social distance rule will be broken.

Again, it is seen that cruise vacations, where safe social distance cannot be kept, is an unpreferable type of tourism. This result may be associated with the cruise market's three major cruise lines, a history of non-payment of federal taxes, poor labor conditions and environmental pollution, which are pointed out by Benjamin et al. (2020). The results of the study, such as the importance of social distance, avoidance of mass movements, rural tourism, hygiene and health issues, are in line with the results of other studies in the literature (Chebli and Said, 2020; Benjamin, Dillette and Alderman, 2020; Ivanova et al., 2020; Turnsek et al., 2020). The absence of a statement about travel insurance can be seen as a lack of information in the study. Travel insurance has been examined in the study of Chebli and Said (2020), and they found that tourists will avoid the risk of traveling without travel insurance. In addition, at the time of the study, the number of published studies was very limited.

The findings of the study are intended to help the industry to build new approaches on developing their products and services during the pandemic. In this context, the issues that tourism sector stakeholders should pay attention to, in order to respond to the developments in travel after Covid-19, can be stated as follows:

- Tourism companies continuing to take health and safety precautions,

- Keeping the safe social distance,

- Conducting activities in a controlled manner with a more limited number of tourists,

- Destination managers focusing on rural tourism,

- The adoption of a sense of slow and local, and 
- To ensure that small businesses are more accessible in this process.

Future studies may examine the impact of Covid-19 on tourist behavior within the scope of socio-demographic variables. It can examine the frequency of the usage of smart technologies during the pandemic and contactless applications in companies. It can be done with in-depth interview technique in order to determine the sub-causes for those who do not plan to make any changes in their travel plans.

\section{References}

Ali, F. and Cobanoglu, C. (2020). Global tourism industry may shrink by more than $50 \%$ due to the pandemic. https://theconversation.com/global-tourism-industry-may-shrink-bymore-than-50-due-to-the-pandemic-134306. Retrieved on April 2020.

Andrades, L., Dimanche, F. and Ilkevich, S. (2015). Chapter 4: Tourist behaviour and trends In book: Tourism in Russia: A management handbook: Emerald Editors.

Benjamin, S. Dillette, A. and Alderman, D. H. (2020). We Can't Return to Normal: Committing to Tourism Equity in the Post-Pandemic Age, Tourism Geographies, 22 (3), 476-483. DOI: 10.1080/14616688.2020.1759130.

Bernard, H. R. (2000). Social Research Methods: Qualitative and Quantitative Approaches. Londra: Sage Yayınları.

Bodosca, S., Gheorghe, S., and Nistoreanu, P. (2014). Tourist consumption behaviour before and after the crisis from 2008. Paper presented at the 21st International Economic Conference 2014, IECS 2014, 16-17 May 2014, Sibiu, Romania. Procedia Economics and Finance.

Carr, A. (2020). COVID-19, Indigenous Peoples and Tourism: a View from New Zealand, Tourism Geographies, 22 (3), 491-502. DOI: 10.1080/14616688.2020.1768433.

Chebli, A. and Said, F. B. (2020). The Impact of Covid-19 on Tourist Consumption Behaviour: A Perspective Article. Journal of Tourism Management Research. 7(2), 196-207.

De Vos, J. (2020). The effect of Covid-19 and subsequent social distancing on travel behavior. Transportation Research Interdiciplinary Perspectives, 5, 1-3.

Díaz-Sánchez, J. P. and Moisés O. (2020). The Effects of Coronavirus (COVID-19) on Expected Tourism Revenues For Natural Preservation. The Case of the Galapagos Islands, Journal of Policy Research in Tourism, Leisure and Events, 1-5. DOI: 10.1080/19407963.2020.1813149.

Enger, W., Saxon, S., Suo, P. and Yu, J. (2020). The way back: What the world can learn from China's travel restart after https://www.mckinsey.com/industries/travel-transport-and-logistics/our-insights/thewayback-what-the-world-can-learn-from-chinas-travel-restart-after-covid-19. Retrieved on April 2020.

Flew, T. and Kirkwood, K. (2021). The impact of COVID-19 on cultural tourism: art, culture and communication in four regional sites of Queensland, Australia. Media International Australia. 178 (1), 16-20. DOI:10.1177/1329878X20952529.

Foo, L. P., Chin, M.-Y., Tan, K.-L. and Kit Teng, P. (2020). The Impact of COVID-19 on Tourism Industry in Malaysia. Current Issues in Tourism. 1-5. DOI: $10.1080 / 13683500.2020 .1777951$.

Gil-Alana, L. A. and Poza, C. (2020). The Impact of COVID-19 on the Spanish Tourism Sector. Tourism Economics. 1-8. DOI: 10.1177/1354816620959914.

Gretzel, U., Fuchs, M., Baggio, R., Hoepken, W., Law, R., Neidhardt, J., Pesonen, J., Zanker, M., and Xiang, Z. (2020). E-Tourism Beyond COVID-19: a Call for Transformative 
Research. Information Technology and Tourism, 22 (2), 187-203. DOI: 10.1007/s40558-020-00181-3.

Ivanova, M., Ivanov, I. K. and Ivanov, S. (2020). Travel Behaviour after the Pandemic: The Case of Bulgaria. Anatolia (in press). 1-12. DOI: 10.1080/13032917.2020.1818267.

Jiricka, A., Brandenburg, C. and Pröbstl-Haider, U. (2020). City Tourism Pre- and PostCovid-19 Pandemic - Messages to Take Home for Climate Change Adaptation and Mitigation?. Journal of Outdoor Recreation and Tourism, 31, 1-6.

Kock, F., Norfelt, A., Josiassen, A., Assaf, A. G. and Tsionas, M. G. (2020). Understanding the COVID-19 Tourist Psyche: The Evolutionary Tourism Paradigm. Annals of Tourism Research. 85. 103053. DOI: 10.1016/j.annals.2020.103053.

Kour, P., Jasrotia, A., and Gupta, S. (2020). COVID-19: a pandemic to tourism guest-host relationship in India. International Journal of Tourism Cities. DOI: 10.1108/IJTC-062020-0131.

Lew, A. A., Cheer, J. M., Haywood, M., Brouder, P., and Salazar, N. B. (2020). Visions of travel and tourism after the global COVID-19 transformation of 2020. Tourism Geographies, 22(3), 455-466. DOI: 10.1080/14616688.2020.1770326.

Neuman, W. L. (2007). Toplumsal Araştırma Yöntemleri Nitel ve Nicel Yaklaşımlar. Cilt 2 (Çev. S. Özge). İstanbul: Yayın Odası.

Patton, M. Q. (2002). Qualitative Research \& Evaluation Methods. ABD: Sage.

Pearce P. L. (2005). Tourist Behaviour: Themes and Conceptual. Clevedon, UK: Channel View Publications.

Renaud, L. (2020): Reconsidering Global Mobility: Distancing from Mass Cruise Tourism in the Aftermath of COVID-19. Tourism Geographies. 22(3), 679-689. DOI: $10.1080 / 14616688.2020 .1762116$.

Robson, C. (2002). Real world research: A resource for social scientists and practitioner researchers (2nd ed.). Oxford: Blackwell.

Rogerson, C. M. and Rogerson, J. M. (2020). Covid-19 Tourism Impacts In South Africa: Government and Industry Responses. GeoJournal of Tourism and Geosites, 31(3), 1083-1091. DOI: $10.30892 / g t g .31321-544$

Roscoe, J. T. (1975). Fundamental research statistics for the behavioral sciences (Second ed.). New York: Holt Rinehart and Winston.

Seraphin, H. (2020). Mountain tourism and second home tourism as post COVID-19 lockdown placebo?. Worldwide Hospitality and Tourism Themes. 12(4), 485-500.

Sharma, A. and Nicolau, J. L.(2020), An open market valuation of the effects of COVID-19 on the travel and tourism industry, Annals of Tourism Research, 83, 102990. DOI: 10.1016/j.annals.2020.102990.

Sigala, M. (2020). Tourism and COVID-19: Impacts and implications for advancing and resetting industry and research. Journal of Business Research. 117, 312-321.

Sultana, J. (2020). Determining the factors that affect the uses of Mobile Cloud Learning (MCL) platform Blackboard- a modification of the UTAUT model, Education and Information Technologies Volume, 25, 223-238.

Swarbrooke, J. and Horner, S. (2007). Consumer Behaviour in Tourism. (2nd ed.). Butterworth-Heinemann: Routledge.

Tatum, M. (2020). Will medical tourism survive covid-19?. BMJ. 370 (m2677). DOI: 10.1136/bmj.m2677.

Thomas, F. (2020). Traveling after COVID. https://www.tourismtransformed.com/uploads/ 2/8/8/4/28845077/traveling_after_covid_18apr-18may2020_fthomas.pdf, Retrieved on April 2020.

Turnsek, M., Brumen, B., Rangus, M., Gorenak, M., Mekinc, J. and Stuhec, T. L. (2020). Perceived Threat of COVID-19 and Future Travel Avoidance: Results from an Early Convenient Sample in Slovenia. Academica Turistica, 13(1), 3-19. 
United Nations World Tourism Organization - UNWTO. (2020). International Tourism and Covid-19. https://www.unwto.org/international-tourism-and-covid-19. Retrieved on March 2021.

United Nations World Tourism Organization - UNWTO. (2020). World Tourism Parameter. https://www.unwto.org/taxonomy/term/347. Retrieved on March 2021.

World Health Organization - WHO. (2020). Novel Coronavirus (2019-nCoV) Situation Report - 121 January 2020, https://www.who.int/docs/defaultsource/coronaviruse/situation-reports/202001

21-sitrep-1-2019ncov.pdf?sfvrsn=20a99c10_4 . 28/07/2020. Retrieved on March 2021.

Yousaf, A., Amin, I., and Santos, J. A. (2018). Tourist's motivations to travel: A theoretical perspective on the existing literature. Tourism and Hospitality Management, 24(1), 115.

\section{Author Bibliograpy}

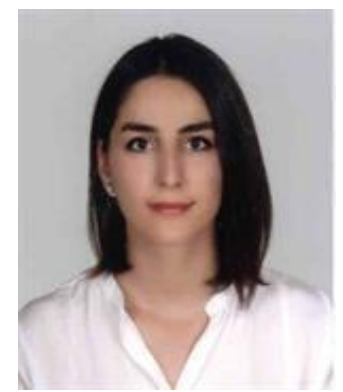

Serap Ozdemir-Guzel graduated from Dokuz Eylul University, Faculty of Business, Department of Tourism Management (English) (2010). Received M.A. degree from Dokuz Eylül University Institute of Social Sciences, Department of Tourism Management (2013), Ph.D. degree from Istanbul University, Institute of Social Sciences, Department of Tourism Management. She is currently lecturer at Istanbul University- Cerrahpaşa, Tourism and Hotel Management program. Basic working areas; Tourism Marketing, Destination Marketing, Tourism Management.

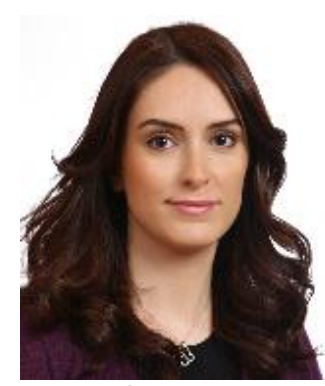

Leyla Şişik received an M.A. degree from Istanbul University, Institute of Social Science, Department of Tourism Management in 2012. Currently working towards the completion of her $\mathrm{PhD}$ degree in the Tourism Management program at Istanbul University. She simultaneously works as a project coordinator on a tourism project conducted by the Republic of Turkey Ministry of Culture and Tourism. She has a background in quality services, tourism development needs in EU funded projects as Non-Key Expert. Her research interests also focus on tourism marketing, food tourism, rural tourism, sustainable tourism. 